\title{
NEW JERSEY AND THE CIVIL WAR: NOTES TOWARD A BIBLIOGRAPHY
}

\author{
BY DONALD A. SINCLAIR
}

I

$T$ is a sad commonplace that books on the various aspects of national history frequently skip over the part played by (or in) New Jersey, or at best give it slight attention. For the most part these gaps could be filled somewhat by a little greater energy on the part of the writers; nevertheless, it must be admitted that scholars without access to the few libraries equipped to guide them in New Jersey history are singularly handicapped as regards sources.

Actually there is a large, valuable body of historical literature dealing with New Jersey, its localities, people, and institutions. In the use of this material, one problem is that of evaluation-it travels the whole range of quality, from good to abominably bad. Most troublesome, however, is the basic problem of simply learning about these materials and locating copies of them. The need is for comprehensive bibliographical tools, which presently do not exist.

After pondering this problem for some time, the writer several months ago began preparation of a bibliography concerned with New Jersey's Civil War history, which should prove of value particularly in the next four years. Under stimulation of the $196 \mathrm{I}-65$ centennial preliminaries, a few monographs dealing with this subject have already been started-chiefly histories of New Jersey regimentsand there are certain to be more. In addition, newspaper journalists throughout the state have begun to do research in the war history, especially of their own localities.

While the bibliography is not yet finished, it has advanced far enough to serve as an image of the final product, and also to yield a few impressions of the subject which may be of interest to readers of the Journal. Let it be noted first, however, that the project is limited to printed books, pamphlets, magazine articles, and (at the moment) broadsides- the last category included on a tentative basis. Two types of source material, for technical reasons, are excluded: newspapers and manuscripts. 
Although primarily concerned with the war period itself, the bibliography includes certain eve-of-the-war items which have special pertinence. Among these are addresses of New Jersey politicians and clergymen early in I86I, facing the prospect of war-e.g., Rev. W. R. Gordon at Schraalenburgh, The Peril of Our Ship of State (a rebuttal of another clergyman's charge that abolitionism threatened the peace). In the light of his subsequent exceedingly brief service in the war, General Runyon's martial address before the New Jersey Military Association, a month before Sumter, is interesting. The Association, incidentally, an organization of militia officers the proceedings of whose meetings were published annually, maintained a non-combat status throughout the war.

There is still need for a first-class history, or several histories, of New Jersey and the Civil War. Soon after the struggle ended, John Y. Foster, a newspaper publisher with useful political connections, was commissioned by the Governor to prepare such a history, which finally appeared in 1868 . It is far from being a definitive work, but, despite several generations of grumbling about it, New Jersey and the Rebellion merits a kindly word or two, chiefly because of the extended section (four-fifths of the book, in fact) containing histories of all the New Jersey military units. Charles M. Knapp's published doctoral dissertation, New Jersey Politics During the Period of the Civil War and Reconstruction (I 924), contributes much of value within its assigned scope. It relies chiefly on contemporary newspapers and the unpublished writings of Charles Perrin Smith, who was long a power in Republican politics. As to the state's municipalities, there are separate Civil War histories of very few-e.g., Rockaway Township, Burlington, etc. On the county level, South Jersey is better supplied than the rest of the state, with Isaac T. Nichols' Historic Days in Cumberland County $\ldots 1855^{-1865}$ and F. H. Stewart's Gloucester County in the Civil $W a r$, the latter essentially modern reprints of wartime items in the Woodbury newspaper. Otherwise one must rely on the irregular, but sometimes extended, Civil War sections contained in the group of county histories chiefly published in the I 880's, when memories of the war survived and interest was still strong. These commonly included lists of the local soldiers, sometimes sketches of the more pertinent regiments or companies. 
Apart from a number of its citizens who enlisted in other states, New Jersey's military contribution to the war is largely told in the histories of forty-odd regiments and other units which were raised here. Sketches of those histories are found in Foster's book (see above); also, in briefer form (along with lists of soldiers), in the two-volume Record of Officers and Men of New Jersey in the Civil War ( 1876$)$.

Because of their sometimes common local origin, as well as the comradeship of hardship shared, members of the various regiments felt an attachment to each other which survived the war in the form of veterans' associations, and reunions were held regularly for many years. As early as $\mathrm{r} 865$, histories of the regiments, in book or pamphlet form, began to appear. In all, about a dozen of these units are the subjects of individual histories, sometimes more than one. Camille Baquet's History of the First Brigade (19I0) tells the story of eight New Jersey regiments, with reminiscences of a few soldiers.

Many of New Jersey's officers and men told their stories in books, pamphlets, or magazine articles. A few of them became more-orless professional veterans, carrying their brevet titles in civilian life, orating and writing frequently on their army experiences. One such was J. Madison Drake who, besides a history of his 9 th Regiment, produced three books and at least one magazine article relating the details of his capture and escape. Drake is described as a colorful character who sported a large pointed goatee and mustaches and frightened the citizens of Elizabeth by riding a spirited black stallion through the streets. Besides Drake's, several of these personal narratives also deal with prison experiences. One of them, published (posthumously) in a recent Wisconsin Magazine of History, was written by a Bavarian immigrant, formerly of Elizabeth, who served, until his capture, in the 3 rd New Jersey Cavalry. War letters and diaries of many New Jersey soldiers have likewise been published in various periodicals over the years-e.g., Col. Honeyman's journal (3 Ist Regt.) in Our Home, I873; Capt. P. J. Kearney's letters (I th Regt.) in the Historical Magazine, I 870.

There are a few reminiscences of a different sort. Jacob R. Freese, in his Secrets of the Late Rebellion. (I882), tells of an infamous provost-court operated by the military governor of Alexandria, of which he was the judge- "Judge Freese's Bayonet Court," as the 
press labeled it. Joseph W. Revere, adventurer, traveler, author of Keel and Saddle ( I 872), was one-time commander of the 7 th Regiment, later courtmartialed and dismissed.

There are a number of biographies, some of a memorial character, not only of military persons but also of political figures such as Governors Parker and Ward. Carlos E. Godfrey wrote a pamphlet in 1907, Sketch of Major Henry Washington Sawyer. Sawyer, subject of an article also in McClure's Magazine, of the Ist New Jersey Cavalry, had the harrowing distinction of being selected, while a prisoner, as one of two officers due for reprisal execution.

Although some of the literature of politics is quite ephemeral, it forms an important part of the Civil War bibliography. There are addresses in Congress by New Jersey Representatives. Nehemiah Perry, a Democrat, discoursed in February, 1863 , on The Omissions and Commissions of the Administration. One S. P. Townsend addressed the Union League at New Providence during the same year, one of his subjects being "the Barbarisms of the Southerners" and "the War a Great National Blessing." Judge R. S. Field gave speeches on constitutional questions concerning the war. Particularly at the end of the war, campaign pamphlets set forth the views of both parties in emotional fashion. The Union Party's Copperhead Love for the Soldier (1865) profited from the war-time issue of absentee votes for soldiers.

The many published sermons dealing with the war show a variety of response, and probably reflect denominational differences. The Episcopalians, although a considerable number of their wartime sermons were preserved in print, have comparatively little comment about the national calamity; rather they discussed such important details as the proper method of baptism, church organization, and the like. The rector at St. John's, Passaic, at the outbreak of war preached on The Nation's Danger and the Nation's Duty, to be sure. In September of the same year, however, a Maryland rector currently supplying a pulpit in Newark ventured a sermon entitled The Sword of the Lord, in which he set forth the Southern point of view.

Methodist and Baptist sermons for the period are not numerous, in pamphlet form, possibly because the church members were less able (or willing) to pay the cost of printing than were those of other denominations. The Calvinists (Presbyterian and Reformed), how- 
ever, seem to have concerned themselves particularly with the war and its problems. Rev. J. H. McIlvaine, in October, I 86I, wrote a long article for the Princeton Review, discussing the nature of the Constitution, the causes of secession, and the need for vigorous prosecution of the war. Other Presbyterians, sometimes in Thanksgiving sermons, exulted over victories at arms and considered the war in the light of duty, God's will, and so on. One gloomy gentleman in I 862 belabored his congregation on Elements and Evidences of $\mathrm{Na}$ tional Decay. Another (denomination undetermined) delivered two lectures at Trenton, early in 1864: How We Got In and How to Get Out.

Of the books, pamphlets, and articles which form the Civil War bibliography of New Jersey, the above gives only a few samples, but sufficient to show something of their character. There is more, of course-a few items of poetry, a play, song sheets, a quantity of postwar material dealing with veterans' activity, monuments, welfare, and so on.

A substantial part of the items found thus far is represented in the collection of the Rutgers University Library. Those which are not, of course, are needed and are sought. Among them, are the following:

Hanifen, M. History of Battery B, First New Jersey Artillery. I 905 .

Campbell, E. L. Historical Sketch of the Fifteenth Regiment. I 880 .

Ferguson, J. Life-Struggles in Rebel Prisons. I 865. Also another edition, I 866.

Forbes, E. Diary of a Soldier. I 865 .

Runyan, M. C. Eight Days with the Confederates. 1896.

Weiser, G. Nine Months in Rebel Prisons. I 890. 